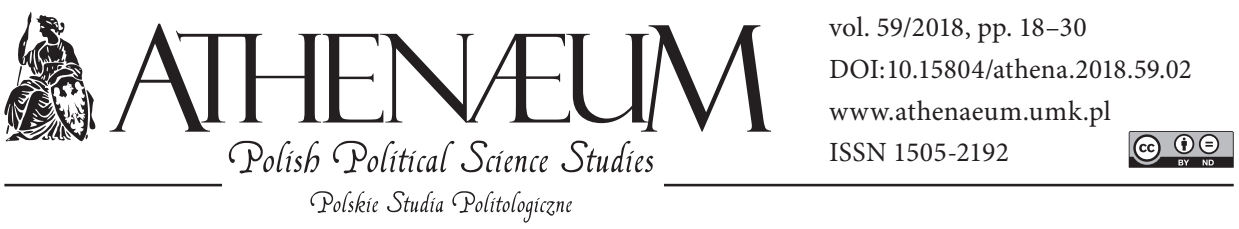

\title{
IS LEFT-WING LIBERALISM POSSIBLE IN POLAND?
}

\author{
CZY MOŻLIWY JEST W POLSCE LIBERALIZM LEWICOWY?
}

\author{
Danuta Plecka*
}

\begin{abstract}
The liberal trend which emerged in Poland was not a doctrine deeply rooted in social awareness. Quite the opposite, its essence and meaning were alien to Polish tradition or hardly recognizable. The interpretation of the concept of freedom only in the negative sense was imposed on the public opinion by the elites. Thus, as new ideas were adopted without any reflection, the state's function was reduced to the role of a "night watchman", and citizens were to adapt to it. Both sides did not enter into discussion on the possible creation of the role of the state as an institution involved in the social sphere. This seems to have been the main cause of the failure of the liberals and of the values they advocated in the public space. The Polish model of liberalism was not on the path towards modernity, but - by treating values selectively - it represented the anachronistic approach to liberal ideas. Polish liberals forgot that in the second half of the $20^{\text {th }}$ century, the welfare state came into being owing to the recognition of Berlin's notion of positive freedom and his unquestioning attitude to the plurality of values. Unfortunately, these two elements did not appear (or appeared too rarely) in the
\end{abstract}

Liberalizm, który pojawił się w Polsce, nie był doktryną zakorzenioną w świadomości społecznej. Wręcz przeciwnie, jego istota i znaczenie były dla polskiej tradycji obce bądź mało rozpoznawalne. Interpretacja idei wolności tylko w sensie negatywnym została narzucona opinii społecznej przez elity. Tym samym bezrefleksyjność przyjmowanych idei usytuowała relację pomiędzy państwem a obywatelem - państwo miało pełnić jedynie rolę „nocnego stróża”, a obywatel miał się do niej dostosować. W przeciwnym wypadku mógłby się narazić na śmieszność bądź podejrzenie o roszczeniowość. Obie strony nie podjęły dyskusji nad możliwym kreowaniem roli państwa jako instytucji zaangażowanej w sferę socjalną. I wydaje się, że to w zasadzie była główna przyczyna przegranej liberałów i wartości przez nich głoszonych w przestrzeni publicznej. Bowiem reprezentowany w Polsce liberalizm nie zmierzał ku nowoczesności, a jedynie wybiórczo traktując wartości, sprzyjał jego anchronicznemu rozumieniu, zapominając, że w 2. połowie XX wieku państwo dobrobytu powstało dzięki uznaniu dla berlinowskiej idei wolności pozytywnej i jego bezdyskusyjnemu stanowisku względem

* University of Zielona Góra, Institute of Political Science. 
liberals' concepts, so left-wing liberalism could not develop in Poland, and its foundations in the economic sphere were taken over by political options other than liberal ones.

Keywords: liberalism, left-right wing, left-wing liberalism pluralizmu wartości. Te dwa elementy niestety nie pojawiły się (albo pojawiały się zbyt rzadko) w koncepcjach liberałów, przez co nie wykształcił się w Polsce liberalizm lewicowy, a jego podstawy w sferze ekonomicznej przejęte zostały przez opcje polityczne obce liberalnym.

Słowa kluczowe: liberalizm, lewica-prawica, liberalizm lewicowy

Liberalism is an ideologically broad, heterogeneous and multidimensional concept. Its representatives are willing to discuss values, social processes or socially approved solutions. As liberalism involves a wide array of views, its individual sections are often contrary to each other, which leads to the conviction that liberalism should be considered in its pluralistic context (Szacki, 1997). It should be emphasized here that no one has ever set any boundaries of liberal thinking and thinking about liberalism. Therefore, ideas traditionally associated with liberalism are interpreted in relatively varied ways. Thus, it is difficult to pursue "liberal orthodoxy" or "model liberalism". This is in line with a common view that "theory, as is well known, is grey and stiff, while the tree of life is green, wind rustles in its branches, so it is hard to classify them in precisely defined categories" (Modzelewski, 2013). This does not mean, however, that there is no basic canon of ideas to which the advocates of this political philosophy may refer to. Quite the opposite, the difference arises only in the sphere of interpretations, which, consequently (apart from other factors), significantly contributes to the emergence of the abovementioned heterogeneity and multitude of liberal ideas (Plecka, 2015).

These differences are often so significant that they locate values deriving from one intellectual tradition on the two opposite ends of the left-right political spectrum. It should obviously be pointed out that the traditional distinction is no longer a point of reference for a number of political scientists, which was reflected especially at the turn of the $20^{\text {th }}$ and $21^{\text {st }}$ centuries. What became the principal argument for the abandonment of the dichotomous division was the transformation in the bloc of Central and East European countries, which brought about changes both in the economic (the introduction of the free market economy) and political sphere (the democratization of the political system). The left-right political divide was deemed an anachronism and it was emphasized 
that "the left and right wing are empty words today" and their specific nature is not adapted to living in modern societies, in which "numerous causes of conflicts no longer allow fighting on one of the sides" (Bobbio, 1996).

This view seems unjustified for at least a couple of reasons. First of all, ideologies based on the views belonging to one of the sides of the traditional left-right dyad are still present in social awareness. Hence, the idea of free market or a hierarchical community will always be attributed to the right wing, while the call for the reduction of class differences will be associated with the left wing. It is obviously quite a simplified division, but it shows the usefulness of ideology in the left-right distinction, thus indicating its permanence (Szawiel, 2002). It should be noted here that while political parties' electoral programmes use the potential of ideologies, politicians tend to forget their ideological roots and do not implement policies connected with them after elections. However, as shown in the study conducted by Arend Lijphart in the years 1945-1996 in 36 democratic countries, ideological orientation (left-wing - right-wing) had a significant impact on the state's socio-economic policy (Lijphart, 1999). Tadeusz Szawiel indicates that Lijphart proved that "in the period under study, left-wing governments were distinguished by: a) consistently higher growth rates of the public sector in the economy, b) higher state budgets, c) more emphasis on the reduction of income inequality, e) more spending on education, healthcare and welfare as compared to right-oriented governments" (Szawiel, 2002a). Therefore, the adopted identity orientation has a considerable influence on the state's policy.

However, the clear presence of the left-right dichotomy in human life changes as the societies develop. Above-quoted Norberto Bobbio believed that "what is the most frequently applied criterion for distinguishing between left and right is the diversity of people's attitudes to the notion of equality" (Bobbio, 1996). In the contemporary world, if we narrow the problem down to the idea of equality as the only dividing line between the left-wing and right-wing, it may imply that this dichotomous division exclusively refers to the economic sphere. Bobbio points out that equality is an idea that has never changed or collapsed over time. However, the adoption of the principle of equality as the only criterion for the left-right distinction is not only the oversimplification of the problem, but it also does not convey the "spirit of changes" which occurred at the turn of the $20^{\text {th }}$ and $21^{\text {st }}$ centuries.

It must be stressed that the economic and political downturn of Central and East European countries occurred beyond the spheres of axiology, which is an important (if not the most important) criterion for building identity. Thus, the 
dividing line between the left and right has shifted from the economic and politi$\mathrm{cal}$ aspects to the sphere of culture. This does not undermine the significance of equality, but it is no longer the only idea which distinguishes the dichotomy. Ideological problems originating from today's globalization processes have become more important - especially in its neoliberal dimension - as well as the measures of democratic scrutiny, the achievements of genetic engineering, euthanasia, etc. (Sierakowski, 2002).

Therefore, it is widely believed that the division into the left and right wing is the consequence of the construction of identity on the basis of axiological systems rather than being the result of economic processes. At the same time, it should be noted that in just a few societies people identify themselves with the left or right because they know and understand their ideologies (Szawiel, 2002a). However, as Talcott Parsons and Niklas Luhmann point out, the notions of "left-wing" and "right-wing" remain symbols-tools used in the process of communication in the public space, because it is required by the complexity and vagueness of a number of political processes. Hence, as Tadeusz Szawiel stresses, "the categories of «left» and «right» reduce this complexity and add meaning to political phenomena, enabling individuals to communicate and navigate in the political space" (Szawiel, 2002a). At the same time, for the concepts of "left" and "right" to exercise their functions, they must meet appropriate criteria, including the generalization (abstraction) of symbols or categories so that they could refer to a wide spectrum of phenomena in the political sphere. The other condition involves the reduction of generalizations so that certain symbols would not be associated with everything because they lose their communication capacity. As a result, the demand arises that "when referring a specific symbol to a concrete phenomenon, problem or area, we must rely on the pairs of two opposites, connected either with the left or with the right" (e.g. workers-capitalists; Grabowska \& Szawiel, 2001).

As it was mentioned before, the left-right distinction is quite an elementary division in this case, serving as a tool for identifying people using it ${ }^{1}$. Thus, it may be used for describing the axiology of the left and right wing. Dino Cofrancesco pointed out that "a man of the right is the one who first of all strives to save tradi-

1 One cannot forget that as the world has become increasingly complex and it is hard to define the place of a man in the universe, "there is room for a number of views located somewhere in the middle between the extreme right and left ideologies, called, as all know, «the centre». [...] grey does not thwart the difference between white and black, and dusk does not eliminate the distinction between night and day" (cf. Bobbio, 1996). 
tion, while a man of the left makes efforts to liberate his neighbours from fetters of race and class privileges (as quoted by: Bobbio, 1996). Elaborating on these assumptions, we may say that, from the axiological perspective, the left-wing prefers individualism, highlights the importance of rights and freedoms, upholds secular attitudes, and supports supranational organizations (Sokół \& Żmigrodzki, 2003). The right-wing, in turn, advocates traditional values, hierarchy, public order and cooperation with the Church, being hostile to all ideas contrary to its teachings (Sokół \& Żmigrodzki, 2003).

In the party system, as Arend Lijphart notes, left and right-wing views are evident in four spheres: first of all, in the division into the state and private ownership of the means of production; secondly, on the axis between the weak and strong role of the government in economic planning; the two other dividing lines are marked by the following relations: supporting or opposing the state's help to economically "poorer" individuals in the society; and, finally, developing or objecting to government welfare programmes (1984).

The above dilemmas and considerations also refer to liberalism, especially to its presence in Poland after 1989. In the history of Poland, liberalism has never shown any features that would allow us to consider it as a deeply rooted doctrine, which has a significant influence on people's lives or on the governing style. It has never been a "complex" of ideas, either, and has only been fragmentarily adopted and applied in various social situations by political actors. This is connected with Polish people's political culture and tradition, the presence and important role of the Catholic Church, and with historical experience. In the period of the most dynamic development of liberal trends in the world, Poles had no statehood, which led to their country becoming economically and socially peripheral. Therefore, a question arises whether what emerged in Poland during the transformation period was the liberal doctrine or whether it was only a loose conglomerate of ideas constructed by its followers in any form, depending on the situation.

It is commonly believed that the advocates of liberal concepts adopted the canon of values based on neo-liberalism. However, these values were not accepted as the doctrinal stereotype, but were treated selectively. Thus, freedom, as the fundamental value of neo-liberalism, was equated with freedom in the economic sphere. As a result, liberalism was located on the right pole of the left-right division axis, and a specific rhetoric - not always characteristic of the liberal doctrine - was developed.

In order to explain this phenomenon, we need to indicate differences in the interpretation of some basic liberal values, such as freedom mentioned above, 
as well as the plurality of values, individualism and equality. What is definitely the most important category in the discussion on the possible emergence of left-wing liberalism in Poland is the idea of freedom. It has often been abused and involved a lot of understatements. The reformers of the transition period trivialized it, narrowing its role down to economic issues. Thus, freedom itself was the synonym of free market rather than referring to the freedom of an individual. We must agree with Andrzej Walicki that "the reduction of the role of liberalism to the promotion of free market is tantamount to the distortion of history. [...] liberalism is a system of views focused on the issue of the maximization of individual freedom. This freedom, being implemented in various spheres and exposed to a number of threats, does not always coincide with market freedom" (Walicki, 2013). In this context, however, it is worth emphasizing that at the turn of the $1980^{\mathrm{s}}$ and $1990^{\mathrm{s}}$ liberalism played the role of the foundation myth of the new state. This myth was obviously to a larger degree promoted by political elites rather than being developed on the grassroots level, although it cannot be said that liberal values were absent in civic awareness.

At the same time, as it was emphasized earlier, liberal concepts were treated quite selectively with some of them even being narrowed down to specific boundaries. This was the case with freedom, the role of which was usually reduced to free market. It should be added that it was connected with economism rather than liberalism, but it also constituted the foundation for interpreting the doctrine from the right rather than left-wing perspective. It contradicted the primary assumption of liberalism, as laid out by Isaiah Berlin, and later by John Rawls, i.e., the absolute plurality of values, often referred to as the "irreducible plurality of values" (Gray, 1995). The interpretation was based on the conviction that there is no single canon of values, and, thus, there are so many of them that "they are incommensurable and often collide with each other, so they should be balanced, because if one of them is absolutized, the others become erased" (Walicki, 2013). Hence, by emphasizing the importance of one of the values, we deny the equivalence of all liberal ideas, which in turn leads to one of them being set apart and, consequently, to the doctrine being located outside the leftwing perspective. Moreover, the promotion of free market, without indicating the state's social obligation, does not favour the left-wing interpretation of the doctrine. For Berlin, Gray or Rawls, it is a proof of the anachronistic view of liberalism.

In Poland, the view that liberalism was related to free market was based on the conviction that the system cannot be changed without deep transformations 
in the economic sphere. That is why the Round Table agreements concerning social and economic issues were not favoured by liberals. It was only the so-called Balcerowicz's plan that they fully approved of ${ }^{2}$. We must emphasize two issues which the liberals have never questioned, and which were interdependent at the same time. First of all, the assumptions of Balcerowicz's plan were largely in line with the expectations of international institutions (the International Monetary Fund and the World Bank), which made their financial aid conditional on Poland's application of specific economic solutions. As Rafał Woś observed, "first non-Communist governments did not have a lot of leeway. One of the reasons was the wild marketization in Poland being the result of Wilczek and Rakowski's famous act (1988). Furthermore, it was Poland's public and private creditors who expected the neoliberal approach from the government in Warsaw. Although they forgave a large part of Poland's debt [...], the cabinets headed by Tadeusz Mazowiecki and Jan Krzysztof Bielecki well knew that Western creditors would be favourably disposed towards Poland only if it followed the recommendations of international financial institutions" (Woś, 2014).

What was the consequence of the above situation was the "unquestionable" nature of the introduced market changes and of the methods implemented to this end. Politicians or intellectuals rarely objected to or disputed this view, following the principle that "free market reforms are difficult, but necessary" (Woś, 2014). Thus, the conviction that there was no alternative to socio-economic reforms led to the widespread criticism of the liberal elites' actions, at the same time making libertarian thinkers focus on the economic sphere exclusively. One cannot also forget about the "sin of constructivism" committed by the liberals. Although the role of the state was reduced to the principle of a "night watchman", liberal thinkers emphasized the need for strengthening it in the period of economic transformation. It was the state that was the institution responsible for constructing free market. Thus, by designing arbitrary changes in the economy, they were against the principle of spontaneous, grass-roots level changes. These efforts may be naturally justified by the lack of alternative or by the legacy of real socialism, e.g., in the form of a large sector of state-owned enterprises, or by the need for handling growing social conflicts. However, from the point of view of the liberal doctrine, this situation contradicted its fundamental principles.

2 As is commonly known, there were huge differences between the Round Table agreements and Balcerowicz's plan: the former "introduced" socialism with a human face, while the latter was a shock therapy introducing free market. 
In its essence, liberalism consisted in the evolution and total abandonment of constructivism; thus, to identify oneself as a liberal, one has to accept the idea of spontaneous development (Hayek, 1978). On the other hand, it is difficult to disagree with Jerzy Szacki, who points out that "in Eastern Europe, liberalism was doomed to constructivism because, unlike in the West, it could not rely on the beneficial effects of dynamic development" (Szacki, 1997).

It may be said that in the 1990s, the activity of liberals was focused on the economy, and other spheres of liberalism were not considered to be the priority. That is why in order to accomplish economic goals, liberal ideas were not introduced to the cultural and political sphere. The liberals were generally of the opinion that freedom in the economy will result in the freedom in politics (the civil society will emerge and, consequently, the state will become decentralized and decisions will be made as close to citizens as possible; the citizens themselves will bear the burden of social welfare, etc.) and in the field of culture (ideological issues will "regulate themselves", and citizens will "grow up" to become free in this matter). What was the cause of this state of affairs was first of all the popular view of liberalism in the version reduced to economism (Karnowska, 2005).

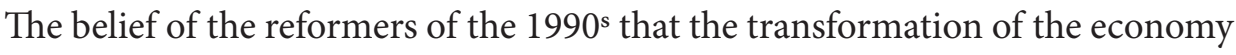
- "switching" it from central planning to free market - will allow them to heal all spheres of life was undoubtedly an illusion, but at the same time it imposed the idea of freedom at the expense of social solidarity in the public discourse, including the political one. Suppressed economic anger, the accusations of excessive demands (which is to say, independent ones), neglect in the sphere of social policy (through actions negating the idea of the welfare state) led to the return to the division between "us" and "them". However, this was not due to the society being opposed to the state, but because of contrasting the notions of "liberal" and "supportive" Poland.

It is political elites that are to blame because, while introducing free market principles in a dogmatic way, they did not take enough care of those social layers which were particularly affected by changes. What is more, what was conducive to the internal division of the society was the fact that politicians took advantage of the weaknesses of social reforms (Karnowska, 2010). Therefore, social solidarity, which is the basis for building democracy based on trust and dialogue, was not the underlying idea of the transformation period. This situation changed when the value of community appeared in the public space, becoming the basic element of the construction of social order around the common good, founded on social solidarity "embedded in the existing human relations, which reveals 
the true, but hidden meaning of these relations" (Taylor, 2005). Thus, there are actually two principal mistakes which result from confining the idea of freedom to the area of the market. Firstly, the very fact that its meaning was narrowed down changed the liberal nature of this value: attributing freedom to individuals so that they could freely decide on their life without being said what good is and how it should be pursued. Secondly, the imposition of free market following Hayek and Friedman's concepts led to a move away from the idea which is complementary to, or even necessary for freedom, i.e., responsibility. This concerns both the economic sphere, in which, in accordance with John Locke's assumptions, individuals utilize as many goods as they are able to produce and consume themselves and as many of them as possible not to be excluded from the use of and access to material resources. Thus, when there are not enough of them, a man is obliged to help those who do not possess them. That is why "charity is not the virtue of the rich, but the right of the poor" (Rawls, 2010).

The fact that the interpretation of the idea of freedom shifted to the right was also determined by another factor. Liberalism, as was mentioned earlier, is the concept related to the freedom of an individual rather than that of a community. In Poland, the tradition of individual freedom, seen as people's right to decide on their own fate, was replaced by thinking about freedom in the context of a national community. It should obviously be emphasized here that the concept of freedom, its interpretation and meaning are very often determined by the cultural contexts of societies, and by their dominant political culture. In the case of Poland, it was undoubtedly related to historical experience. What was of crucial importance was the fact that in the period of the most dynamic and fruitful development of liberalism in the world, Poland was not a sovereign country and Poles fought for independence under the slogan of "regaining freedom". The concept of collective freedom obviously prevailed over the notion of individual freedom in those days. Thus, the category of freedom in the liberal approach was confused with national freedom. As Isaiah Berlin rightly remarks, "the ideal of national freedom is understood as seeking to be «ruled» by members of one's own group, but has nothing to do with the liberal freedom of an individual" (Berlin, 1994).

This way of thinking was reflected in yet another definition of freedom after 1989. Its advocates often refer to Republican traditions, thus, perceiving freedom in the collective sense, but seeing the community predominantly from the political perspective. As a result, this approach assumes citizens' moral obligation of political participation, i.e., their conscious involvement in all efforts taken for the common good. This was in contrast to freedom in the liberal sense and its 
underlying value was the "individualist concept, which makes an individual the subject of freedom and makes the private sphere become the proper area of freedom, free of public obligations" (Walicki, 2013).

Freedom in the Republican sense also contradicts the absolute plurality of values preferred both by Berlin and Rawls. In the case of Poland, the opponents of liberalism often criticized the right to plurality in the sphere of values and morality. They accused liberalism and its followers of the "relativization of values and approving of all compromises, which led to moral chaos" (Krasnodębski, 1997). These remarks mainly referred to politics, but also to the sphere of culture. Thus, there were demands that procedural (liberal) democracy be replaced with its substantialist version, which was typical of Republican thinking. Although absolute plurality would give place to a proper canon of values, it would be conducive to social development (Krasnodębski, 1997).

Such an approach, as was mentioned earlier, is contrary to modern left-wing liberalism, and favours right-wing rhetoric. Liberalism first of all consists in "the liberation of an individual from any forms of authoritarian collectivism", because "it is not and it does not want to be the only overpowering moral and ideological doctrine; it sanctions the irreducible moral and ideological plurality and seeks morally acceptable rules that govern the coexistence of people of various religious, philosophical and ethical views" (Walicki, 2000). We can even risk a statement that each modern society will strive to implement the liberal minimum programme (which concerns plurality), as "it is only a relatively permanent and self-reproductive system of cooperation between equal individuals, so it requires fair rules of coexistence, acceptable from the point of view of different ideologies and excluding the use of coercive measures by the state in order to make any of them dominant" (Walicki, 2000).

These views prevailed in Poland and what became the dominant moral belief was the ethics based on Catholic values instead of the conviction that the absolute plurality of values should be used. The entities responsible for this were the liberals gathered around the free market idea, but also the institution of the Polish Catholic Church. It is safe to say that advocates of liberal concepts were well aware of the fact that the economic reforms after 1989 needed a favourable response from the Catholic Church hierarchs. Thus, they were willing to sacrifice some political and cultural ideas of liberalism for the implementation of the established economic programme.

As far as the economy is concerned, the liberals did not allow for any compromise. Moreover, they expected the Catholic Church to sustain social patience 
in enduring hardship caused by the reforms, to contribute to the development of work ethos and consumption, and to give up its attempts to find a "third way". Steps taken in the economic sphere were aimed at restoring economic stability. Liberalization efforts were to create the foundations of market economy.

The problem of the liberals' attitude to Christian values was the main subject of the debate on the presence of liberal ideas in Poland after 1989. It was especially Catholic and conservative circles that treated liberalism as a threat to Christian values, especially Catholic ones in their institutional form. However, it was not reasonable of the representatives of these circles to renew a dispute between liberal and Christian ideas. It should be noted here that from the historical perspective, liberalism developed first of all as an opposition to the appropriation of awareness and morality by Catholic institutions. Nevertheless, the conflict between these two entirely different trends during the transformation of the system was not conducive to the construction of capitalism and to the improvement of the quality of the society.

Efforts to establish a common platform for liberal and Catholic ideas were motivated by the strong presence of religion in social awareness and the lack of knowledge of the concept of liberalism. Apart from that, it was an attempt to transfer liberal ideas to the Polish ground. As is widely known, each society creates specific conditions for the development of specific ideas. This was the case in Poland, too. For the liberals, strong respect for Catholic tradition was a guarantee that the doctrine would be present in social, political and economic life. On the other hand, the adaptation to local conditions helped to create the principles of Polish liberalism. That is why liberalism, which came in for a lot of criticism, was more consistent with the liberal stereotype than with the ideas that were commonly expressed by the supporters of the doctrine. What is more, it was evident that the liberals tried to impart a Christian character to liberalism or at least make it free of any aversion to Christianity or Catholicism (Szacki, 1997).

The above deliberations allow me to say that one of the causes of the "rightwing bias of Polish liberalism" is also the elites' attitude to the doctrine. On the one hand, it was these political and intellectual elites that contributed to the narrowing down of the meaning of freedom to its market dimension. The liberal trend which emerged in Poland was not a doctrine deeply rooted in social awareness. Quite the opposite, its essence and meaning were alien to Polish tradition or hardly recognizable. The interpretation of the concept of freedom only in the negative sense was imposed on the public opinion by the elites. Thus, as new ideas were adopted without any reflection, the state's function was reduced 
to the role of a "night watchman", and citizens were to adapt to it. Both sides did not enter into discussion on the possible creation of the role of the state as an institution involved in the social sphere. This seems to have been the main cause of the failure of the liberals and of the values they advocated in the public space. The Polish model of liberalism was not on the path towards modernity, but - by treating values selectively - it represented the anachronistic approach to liberal ideas. Polish liberals forgot that in the second half of the $20^{\text {th }}$ century, the welfare state came into being owing to the recognition of Isaiah Berlin's notion of positive freedom and his unquestioning attitude to the plurality of values. Unfortunately, these two elements did not appear (or appeared too rarely) in the liberals' concepts, so left-wing liberalism could not develop in Poland, and its foundations in the economic sphere were taken over by political options other than liberal ones.

\section{REFERENCES:}

Berlin, I. (1994). Cztery eseje o wolności. Warszawa: Wydawnictwo Naukowe PWN.

Bobbio, N. (1996). Prawica i lewica. Kraków-Warszawa: Znak, Fundacja im. Stefana Batorego.

Grabowska, M., \& Szawiel, T. (2001). Budowanie demokracji. Podziały społeczne, partie polityczne i społeczeństwo obywatelskie w postkomunistycznej Polsce. Warszawa: Wydawnictwo Naukowe PWN.

Gray, J. (1995). Isaiah Berlin. London: Princeton University Press.

Hayek, F.A. (1978). New Studies in Philosophy, Politics, Economics and the History of Ideas. Chicago: Routledge \& Kegan Paul.

Karnowska, D. (2005). W kierunku liberalizmu? Recepcja idei liberalnych $w$ Polsce $w$ warunkach transformacji ustrojowej. Toruń: Wydawnictwo Adam Marszałek.

Karnowska, D. (2010). „Solidarność” jako środowisko antyliberalne na polskiej scenie politycznej. In: K. Sobolewska-Myślik, A. Hess, \& K. Kowalczyk (eds.), Polska scena polityczna. Środowiska - komunikacja polityczna - strategie (pp. 30-38). Kraków: Wydawnictwo Uniwersytetu Jagiellońskiego, Wydawnictwo Naukowe Uniwersytetu Pedagogicznego.

Krasnodębski, Z. (1997). Polityka i moralność - w ogóle, u nas i gdzie indziej. Znak, 7, 4-19.

Lijphart, A. (1999). Patterns of Democracy: Government Forms and Performance in Thirty-Six Countries. New Haven, London: Yale University Press.

Plecka, D. (2015). Liberalizm w Polsce na przełomie XX i XXI wieku. Zarys problemu. In: M. Marczewska-Rytko, \& W. Ziętara (eds.), Ideologie, doktryny, ruchy społeczne i polityczne. Wybrane problemy (pp. 185-194). Lublin: Wydawnictwo Uniwersytetu Marii Curie-Skłodowskiej. 
Rawls, J. (2010). Wykłady z historii filozofii polityki. Warszawa: Wydawnictwa Akademickie i Profesjonalne.

Sierakowski, S. (2002). Co dzieli lewicę i prawicę i dlaczego nie ma to znaczenia we współczesnej Polsce. Krytyka Polityczna, 2, 33-49.

Sokół, W., \& Żmigrodzki, M. (2003). Współczesne partie i systemy partyjne. Zagadnienia teorii i praktyki politycznej. Lublin: Wydawnictwo Uniwersytetu Marii CurieSkłodowskiej.

Szawiel, T. (2002a). Trwa i będzie trwał długo. Krytyka Polityczna, 2, 51-63.

Szawiel, T. (2002b). Podział na lewicę i prawicę w Polsce po 1989 roku - jego sens i trwałość. In: R. Markowski (ed.), System partyjny i zachowania wyborcze. Dekada polskich doświadczeń (pp. 178-216). Warszawa: Instytut Studiów Politycznych Polskiej Akademii Nauk, Fundacja im. Friedricha Eberta.

Szacki, J. (1997). Liberalizm niejedno ma imię. Gazeta Wyborcza, 3, 11. February 8-9. Taylor, Ch. (2005). Kilka refleksji na temat solidarności. Znak, 8, 22-34.

Walicki, A., (2000). Polskie zmagania z wolnością. Widziane z boku. Kraków: Universitas. Walicki, A. (2013). Od projektu komunistycznego do neoliberalnej utopii. Kraków: Towarzystwo Autorów i Wydawców Prac Naukowych Universitas, Polska Akademia Nauk. Woś, R. (2014). Dziecięca choroba liberalizmu. Warszawa: Wydawnictwo Studio Emka. 